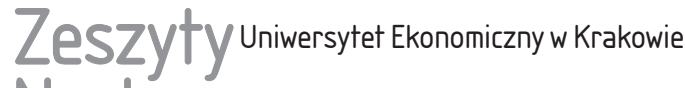 Naukowe
}

\section{Porównywanie w metodzie analizy statystycznej rynku wykorzystywanej do szacowania wartości nieruchomości w Polsce}

\section{Streszczenie}

Metodę analizy statystycznej rynku (MASR) zaliczono w Polsce do podejścia porównawczego. Takie rozwiązanie jest odmienne od przyjętego w teorii wyceny i praktyce rynków rozwiniętych, np. USA. Wykorzystując tę metodę wyceny, nie przeprowadza się porównań, które pozwalałyby na odzwierciedlenie zachowania uczestników rynku. Celem artykułu jest ocena MASR w kontekście metody porównawczej w ekonomii oraz teorii i praktyki wyceny z uwzględnieniem aktualnego orzecznictwa sądowego i przedstawienie w zarysie rozwoju tej metody w Polsce. Wykorzystano studia literatury krajowej i zagranicznej, badanie porównawcze metodyki krajowej i amerykańskiej i krytyczną analizę orzecznictwa sądowego. Przedstawiono propozycję wyłączenia MASR z podejścia porównawczego przewidzianego do określania wartości rynkowej pojedynczych nieruchomości na rzecz celów szacowania związanych z masową wyceną.

Słowa kluczowe: metodyka szacowania wartości nieruchomości, metoda analizy statystycznej rynku, porównania w ekonomii i wycenie nieruchomości, wycena masowa. Klasyfikacja JEL: R30, D04, D70. 


\section{Wprowadzenie}

Porównania w szacowaniu wartości nieruchomości ukształtowały się w dwóch różnych obszarach ludzkiego działania. Pierwszy, praktyczny, związany jest z celowym działaniem człowieka, który przeprowadza porównania przy podejmowaniu różnych decyzji i ocenia także w ten sposób uzyskane efekty. Stosowanie w szacowaniu wartości nieruchomości metod porównawczych umożliwia odwzorowanie zachowania ludzi na rynku. Służą do tego dość proste metody, np. porównywanie parami, które pozwala naśladować sposób podejmowania decyzji przez uczestników rynku nieruchomości. Drugi obszar dotyczy oddziaływania nauki i kwestii metodycznych. Powszechność porównań powoduje, że komparatystyka uzyskała status metody naukowej. Dzięki formalizacji i ustrukturyzowaniu procesu metody porównawcze umożliwiają zobiektywizowane poznawanie analizowanych zjawisk. Dorobek przenoszony z nauki do praktyki szacowania dotyczy przede wszystkim narzędzi. Najczęściej wykorzystuje się regresję wieloraką, która pozwala na analizę dużych ilości danych i jednocześnie poddaje się dość jednoznacznym testom pozwalającym na formalną ocenę poprawności wykonanych obliczeń. Problemem pozostaje uwzględnianie pełnego kontekstu metodyki porównawczej, która obejmuje na poziomie nauki ekonomii: obiekty, ich właściwości pozwalające na porównanie, metody porównywania i ich cele oraz wynik porównania (Nauki ekonomiczne... 2015, s. 44).

Szacowanie wartości nieruchomości ma charakter konceptualny (Kucharska-Stasiak 2016, s. 198), stąd kluczowe znaczenie ma wywodzony z teorii i praktyki badań społecznych (Babbie 2005, s. 139 i nast.) podział procesu szacowania na fazy konceptualizacji i operacjonalizacji, które winny poprzedzać fazę pomiaru. W przypadku przeniesienia z nauki do praktyki szacowania jedynie metod (narzędzi) porównawczych nie jest możliwy obiektywny pomiar wartości rynkowej, gdyż brakuje kryteriów do oceny poprawności tego procesu w fazie konceptualizacji i operacjonalizacji. Wtedy to metoda porównawcza staje się samodzielnym i jedynym uzasadnieniem poprawności całego procesu według własnych kryteriów, które są wcześniej wbudowane w model obliczeniowy. Z taką sytuacją, prowadzącą do braku możliwości obiektywizacji całego procesu wyceny, możemy mieć do czynienia przy błędnym stosowaniu MASR, która w obszarze nauki ma opisane formalnie warunki umożliwiające uznanie pomiaru za obiektywny na poziomie narzędziowym, czyli przy ocenie ograniczonej do wymiaru umiejętności (techne). 


\section{Ramy koncepcyjne}

W artykule porównania rozumiane są wąsko jako sformalizowane prawnie czynności rzeczoznawców majątkowych (praktyków) prowadzące do określenia wartości rynkowej nieruchomości w formie operatu szacunkowego. Wymaga to korzystania ze sposobów wyceny przewidzianych w przepisach (Ustawa z dnia 21 sierpnia 1997 r. ..., dział IV; Rozporządzenie Rady Ministrów z dnia 21 września 2004 r....), które w różnym stopniu pozwalają na odzwierciedlenie złożonych relacji rynkowych. W Polsce jedną z metod zaliczonych do podejścia porównawczego jest MASR (Rozporządzenie Rady Ministrów z dnia 21 września 2004 r. ..., par. 4, ust. 2). Opisany we wprowadzeniu pierwszy obszar metodyczny (praktyki działania ludzi) kształtuje porównania w analogii do świata sztuki i poznania typu doksa z problemami wyobrażeń i wiary oraz poznawania pośredniego lub bezpośredniego. Jest to bliskie naśladowania natury i próby pośredniego odwzorowania umiejętności rynkowych człowieka, który pomimo zwiększającego się interwencjonizmu nie utracił doświadczenia i wiary, że rynek prowadzi do wyniku gry o sumie dodatniej i w ten sposób tworzy się bogactwo (Ayou 2010). Drugi obszar dotyczy pomiaru ścisłego i dokładnego (poznania typu epistyme), uznawanego za synonim wiedzy pewnej i pomiaru naukowego, właściwego dla nauk ścisłych, np. fizyki czy mechaniki. Korzysta się tam metodologicznie z eksperymentów kontrolowanych, które zapewniają wysoką formalną pewność wyników uzyskiwanych dzięki zastosowaniu dobrych narzędzi do pomiaru. Wskazane dwa obszary inspirują procesy porównywania w szacowaniu wartości nieruchomości i sytuują działalność praktyków bliżej „sztuki” (wrażeń) lub „nauki” (ścisłości). MASR, w tym ujęciu, formalnie zbliża się do nauki, poznania ścisłego i niezawodnego dzięki stosowaniu naukowych narzędzi. Przeniesienie wprost do szacowania wartości nieruchomości metod wykorzystywanych w doświadczalnych dyscyplinach naukowych nie jest uzasadnione, ale korzystanie z dorobku metodologicznego ekonomii jest uargumentowane, gdyż teoria szacowania wartości nieruchomości zaczyna się od definiowania i interpretacji kategorii wartości rynkowej, której korzenie tkwią w ekonomii (Mooya 2016, Canonne i Macdonald 2003, s. 113 i nast.). Do zapewniania procesowi szacowania obiektywacji niezbędne jest uporządkowanie metodologiczne porównań według kryteriów wywodzonych z metodologii ekonomii. Wymaga to poprzedzenia stosowania metody (pomiaru) fazą konceptualizacji odnoszoną do definiowania i interpretacji podstawy wyceny (np. wartości rynkowej) i fazą operacjonalizacji dotyczącej poznania warunków funkcjonowania rynku i w następnym kroku zebrania właściwych danych do wyceny. W tabeli 1 przedstawiono propozycję uporządkowania zasad metodycznych szacowania wartości nieruchomości w podejściu porównawczym według modeli hierarchicznie ujmujących trzy etapy procesu wyceny. 
Tabela 1. Możliwe uporządkowanie zasad wyceny według modeli

\begin{tabular}{|l|c|c|c|c|c|}
\hline \multirow{2}{*}{ Kryteria } & \multirow{2}{*}{$\begin{array}{c}\text { Faza procesu } \\
\text { poznania }\end{array}$} & \multicolumn{4}{|c|}{ Model szacowania } \\
\cline { 3 - 6 } & normatywny & pozytywny & narzędziowy & funkcjonalny \\
\hline Istota & $\begin{array}{c}\text { konceptuali- } \\
\text { zacja }\end{array}$ & wartość & rynek & metoda & $\begin{array}{c}\text { wartość jako } \\
\text { funkcja cen }\end{array}$ \\
\hline $\begin{array}{l}\text { Środowisko } \\
\text { analiz }\end{array}$ & $\begin{array}{c}\text { operacjonali- } \\
\text { zacja }\end{array}$ & rynek & metoda & rynek & metoda \\
\hline Algorytm & pomiar & metoda & wartość & wartość & rynek \\
\hline
\end{tabular}

Źródło: opracowanie własne.

Oprócz trzech podstawowych modeli szacowania wprowadzono specyficzny model funkcjonalny stosowany w Polsce (Konowalczuk 2017, s. 52 i nast.). W przypadku przenoszenia z ekonomii narzędzi ilościowych do praktyki szacowania wartości nieruchomości istnieje realne zagrożenie nadania nadrzędnego znaczenia metodzie i uporządkowania wyceny według modelu narzędziowego lub pozytywnego, podczas gdy poprawny jest model normatywny.

\section{Przegląd literatury, krajowych regulacji prawnych i orzecznictwa sądowego}

Prekursorem instytucjonalizacji prawnej MASR była nieformalna publikacja administracji rządowej (Tymczasowe zasady... 1994, s. 34). Przy jej opracowaniu pominięto pierwsze krajowe publikacje dotyczące teorii wyceny, w których regresja wieloraka została, zgodnie z literaturą anglosaską, wyłączona z podejścia porównawczego (Hopfer i in. 1994, s. 84, 113 i nast.). Sposób wyceny nazywany metodą analizy statystycznej rynku wprowadzono do regulacji prawnych w Polsce w 1995 r.i od początku zaliczano do porównawczych metod wyceny. Początkowo była to technika analizy statystycznej rynku w ramach metody cenowo-porównawczej (Zarządzenie Ministra Gospodarki Przestrzennej i Budownictwa z dnia 1 marca 1995 r. ..., par. 9.1). Od 1998 r., po kompleksowej instytucjonalizacji prawnej metodyki wyceny (Ustawa z dnia 21 sierpnia 1997 r. ...), nazywana jest metodą i zaliczana formalnie do podejścia porównawczego (Rozporządzenie Rady Ministrów z dnia 7 lipca 1998 r. ..., par. 5). Status prawny tej metody ustalono w przepisach prawa dopiero w 2002 r. (Rozporządzenie Rady Ministrów z dnia 27 listopada 2002 r. ..., par. 5.1). Aktualnie dla MASR nadal obowiązuje jedynie namiastkowa regulacja prawna na poziomie przepisu wykonawczego (Rozporządzenie Rady Ministrów z dnia 21 września 2004 r. ..., par. 4). Regulacje prawne MASR poprzedzające aktualne rozwiązania metodyczne w zakresie porównań były następujące: 
- 1995 r. - do porównań przyjmuje się grupę nieruchomości stanowiących próbkę reprezentatywną na lokalnym rynku (Zarządzenie Ministra Gospodarki Przestrzennej i Budownictwa z dnia 1 marca 1995 r...., par. 10, ust. 3);

- 1998 r. - do porównań przyjmuje się grupę nieruchomości reprezentatywnych dla rynku właściwego miejscowo ze względu na położenie wycenianej nieruchomości, jeżeli były one przedmiotem obrotu rynkowego i dla których znane są ceny transakcyjne, warunki zawarcia transakcji, a także cechy tych nieruchomości (Rozporządzenie Rady Ministrów z dnia 7 lipca 1998 r. ..., par. 5, ust. 4);

- 2002 r. - do porównań przyjmuje się próbę nieruchomości reprezentatywnych. Wartość nieruchomości określa się przy użyciu metod stosowanych do analiz statystycznych (Rozporządzenie Rady Ministrów z dnia 27 listopada 2002 r. ..., par. 4, ust. 4).

Odmiennie niż dla metody porównywania parami i korygowania ceny średniej w przypadku MASR od 2002 r. przepisy nie wskazują na dokonywanie porównań i odwołują się do próby nieruchomości reprezentatywnych. Namiastkowy charakter porównań w MASR jest złagodzony przez formalne zaliczenie do podejścia porównawczego, które korzysta z założenia wykonywania korekt ze względu na cechy różniące porównywane nieruchomości. Dlatego część praktyków traktuje MASR jako równoprawną metodę porównawczą, chociaż w literaturze wskazuje się, że intencją ustawodawcy było jedynie uregulowanie w ten sposób metodyki wyceny nieruchomości reprezentatywnej przy ustalaniu wartości katastralnej $^{1}$ (Dydenko i Telega 2016, s. 155). Poza tym regulacje prawne MASR są wyjątkowo nieprecyzyjne i formalnie sporne (Kosmulska 2016) lub nie są rekomendowane dla praktyki (Małecki 2016). Orzecznictwo sądów administracjach i cywilnych nie kwestionuje uniwersalnego charakteru MASR jako jednej z metod porównawczych, dopuszczając jej wykorzystanie do tak specyficznych celów, jak: aktualizacja opłaty rocznej za użytkowanie wieczyste, opodatkowanie podatkiem dochodowym, pobieranie opłat publicznych z tytułu użytkowania wieczystego, opłaty planistycznej, opłat adiacenckich (Wyrok SO w Warszawie z dnia 24 maja 2016 r...., Wyrok WSA w Gliwicach z dnia 20 marca 2015 r. ..., Wyrok WSA we Wrocławiu z dnia 19 marca 2004 r...), rozliczenia przy zachowku (Wyrok SO w Łodzi z dnia 4 maja 2016 r....). Krytyka tej metody dotyczy jedynie niskiej efektywności w wycenie pojedynczych nieruchomości z powodu wysokich kosztów

\footnotetext{
${ }^{1}$ Do tego celu MASR nie stanowi samodzielnej metody szacowania wartości konkretnej nieruchomości. Służy do oszacowania wartości nieistniejącej w rzeczywistości nieruchomości reprezentatywnej (Ustawa z dnia 21 sierpnia 1997 r. ..., art. 161, ust. 1), która jest wykorzystana do ustalenia w procedurze administracyjnej wartości katastralnej. Kluczowym elementem tej procedury jest specyficzna administracyjna wycena porównawcza prowadząca do ustalenia przez organ wartości katastralnej konkretnej nieruchomości według specyficznych zasad metodycznych (por. Rozporządzenie Rady Ministrów z dnia 29 czerwca 2005 r....).
} 
pracy biegłych (Wyrok SO w Gliwicach z dnia 2 grudnia 2014 r. ...). W sprawach dotyczących wyceny szkód w obszarach ograniczonego użytkowania portów lotniczych sądy także nie kwestionowały wyboru tej metody (Wyrok SO w Warszawie z dnia 22 lutego 2016 r. ..., Wyrok SO w Poznaniu z dnia 21 kwietnia 2016 r...., Wyrok SA w Poznaniu z dnia 14 kwietnia 2016 r...., Wyrok SO w Łodzi z dnia 4 maja 2016 r. (a)..., Wyrok WSA w Gliwicach z dnia 25 września 2013 r. ...).

Nie należy przeceniać znaczenia komentarzy prawników i orzeczeń sądów dla oceny przydatności metodycznej MSAR do szacowania porównawczego wartości nieruchomości. Interpretacje sądów mają bowiem w systemie prawa stanowionego formalne ograniczenia, a prawnikom brakuje specjalistycznej wiedzy z zakresu metodyki. Przykładowo zmieniona w 2002 r. klasyfikacja prawna sposobów wyceny spowodowała istotne problemy interpretacyjne dla sądów przy ustalaniu, czy mamy do czynienia $\mathrm{z}$ tą samą metodą wyceny obejmującą dwie formuły obliczeniowe, czy raczej są to różne sposoby wyceny przed zmianami i po zmianach (Wyrok WSA w Warszawie z dnia 25 marca 2004 r....) ${ }^{2}$. Przepisy prawa przyznają rzeczoznawcy kompetencje wyboru sposobu szacowania wartości konkretnej nieruchomości (Ustawa z dnia 21 sierpnia 1997 r. ..., art. 154), gdyż wymaga to wiedzy specjalistycznej. Ten obszar metodyki szacowania wyłączony jest z zakresu interpretacji prawników i oddany do rozstrzygnięcia rzeczoznawcy, który winien posiadać wiedzę specjalistyczną obejmującą także kwestie znajomości metodyki szacowania na tle teorii badań społecznych.

W literaturze naukowej wskazuje się wiele metod analizy statystycznej, różnorodne ich zastosowanie oraz przedstawia się dwa obszary praktycznego zastosowania. Dotyczą one wyceny masowej oraz szacowania wartości pojedynczej nieruchomości (Adamczewski 2006, s. 12; Hozer, Kokot i Kuźmiński 2002, s. 8). Niektórzy autorzy utożsamiają metody masowe wyceny z MASR (Zbyrowski 2010, s. 241; Sawiłow 2010; Czaja 2004). W praktyce standaryzacji międzynarodowej problematyka masowej wyceny omawiana jest głównie w kontekście efektywności i sprawiedliwości pobierania podatku katastralnego (Międzynarodowe standardy... 2009, s. 275 i nast.).

Odróżnianie narzędzi statystycznych służących do wykonania analizy rynku od metody służącej do określania wartości rynkowej ma kluczowe znaczenie dla poprawnego stosowania MASR (Foryś 2012, s. 12-18). Dla wstępnego zobrazowania różnicy w tym zakresie można wykorzystać sugestywne ujęcie praktyczne, które analizę rynku nazywa procesem wyceny odwrotnej (Europejskie standardy... 2001, s. 286). W literaturze naukowej prezentuje się najczęściej MASR w modelu narzędziowym, który zaciera proceduralne granice metodyczne odręb-

\footnotetext{
${ }^{2}$ Teza uzasadnienia: „Skoro zatem nowe rozporządzenie rozróżnia wszystkie trzy metody, to nie można uznać za zasadne stwierdzenia, że dwie z tych metod są metodami tożsamymi”, wskazuje na istotne ograniczenia poznawcze sądu.
} 
nych czynności analizy rynku i obliczania wartości nieruchomości (Barańska 2007, s. 187-196; Adamczewski 2006; Hozer 2001, s. 13-14). Część autorów wyodrębnia problematykę wykorzystania metod ilościowych do analiz rynku wykonywanych na potrzeby szacowania wartości nieruchomości (Foryś 2017, s. 60-68; Foryś i Gaca 2016a, s. 89-100; Foryś i Gaca 2016b, s. 89-100; Foryś 2014, s. 59-68; Foryś i Batóg 2011, s. 34-48). Zasadniczo w literaturze krajowej niewiele miejsca poświęca się problemowi operacjonalizacji badań. Specyficzna jest także sytuacja MASR z punktu widzenia standaryzacji zawodowej, gdyż pomimo podejmowanych prób nie zdołano wypracować normy zawodowej (Kokot 2011, s. 7).

W USA najpowszechniej wykorzystywaną metodą statystyczną w procesie szacowania wartości nieruchomości, wycenie masowej, automatycznych modelach wyceny (w skrócie: AVM) i innych formach analiz rynku nieruchomości jest analiza regresji (The Appraisal... 2013, s. 733; Dell 2004, s. 12-17). Metody statystyczne uznaje się za potężne narzędzia przydatne do agregowania i opisywania danych oraz do wnioskowania o parametrach populacji i budowy modeli predykcyjnych. Praktyka ich stosowania wywołuje wielowątkowe dyskusje ${ }^{3}$ w środowisku akademickim i praktyków (Trimble 2014, s. 172-175; Robinson i Sanderford 2016, s. 311-322). Trwa tam wielowątkowa dyskusja dotycząca stosowania metod statystycznych do wyceny pojedynczych nieruchomości, od kwestii fundamentalnych po szczegółowe kwestie metodyczne (Dell 2013, s. 332 i nast.). Prezentowane są skrajne poglądy o nadrzędności modeli ekonometrycznych nad tradycyjnymi metodami wyceny i opinie o konieczności ich powszechnego i swobodnego stosowania do wycen pojedynczych nieruchomości, w tym z wykorzystaniem AVM (Pasymowski 2006). Zgodnie przyjmuje się, że uzasadnione jest stosowanie zaawansowanej statystyki do analizy dużych zbiorów danych, analiz rynku i wyceny masowej. Problematyczne jest stosowanie zaawansowanych metod statystycznych do wyceny pojedynczej nieruchomości i rekomendacji takiej nie udziela Appraisal Institiute. Formułuje się także poglądy, że w przyszłości może nastąpić rozwój trzech tradycyjnych podejść do wyceny i metody statystyczne mogą albo zostać zintegrowane z jednym z nich, albo stanowić odrębne podejście (Kane, Linne i Johnson 2004, s. XI). Jednakowo przyjmuje się, że warunkiem stosowania metod statystycznych jest zgodność z teorią wyceny i wypracowanymi zasadami wyceny (np. substytucji) oraz z teorią wartości. Wymaga to uwzględniania różnicy pomiędzy wartością a ceną (Wolverton 2014, s. 176). Wskazuje to na stosowanie w USA modelu normatywnego do określania wartości rynkowej pojedynczej nieruchomości, co przy konceptualizacji wartości według zasad analizy HBU wyklucza MASR z podejścia porównawczego.

\footnotetext{
${ }^{3}$ Jeden z rzadziej omawianych problemów dotyczy spełniania przy stosowaniu MASR warunku poprawnego doboru próby statystycznej, która reprezentowałaby badaną populację. Szerzej zob. (The Appraisal... 2013, s. 750).
} 
W dyskusji prowadzonej w USA zabrakło głosów za zaliczeniem metod ilościowych do podejścia porównawczego. Problem ten jednoznacznie rozstrzygnięto także w Europie przed ponad 20 laty (Europejskie standardy... 2001, s. 289). Krajową regulację prawną, która zalicza MASR do podejścia porównawczego, uznać należy za metodycznie błędną. Jednocześnie zaliczenie MASR do podejścia porównawczego tworzy obecnie w Polsce podstawowe ograniczenie metodyczne swobodnego korzystania z narzędzi statystycznych. Nie ogranicza to sposobów analizy rynku, a jedynie metody wyceny. Problemem jest specyficzne i słabo metodycznie uzasadnione ograniczenie prawne wskazujące na tworzenie zbioru danych do wyceny, które mają być położone na „obszarze gminy, a w przypadku braku dostatecznej liczby transakcji, na obszarze gmin sąsiadujących" (Ustawa z dnia 21 sierpnia 1997 r. ..., art. 161, ust. 2). Tego rodzaju ograniczenia zakresu przestrzennego analizy rynku nigdy nie sformułowano dla metody porównywania prawami, a dla korygowania ceny średniej ograniczenie tego rodzaju zniesiono w 2010 r. (Rozporządzenie z dnia 21 września 2004 r...., par. 4, ust. 4).

\section{Porównania $w$ wybranych dziedzinach ekonomii a metodyka szacowania wartości nieruchomości}

Aby przeprowadzić dalsze rozważania dotyczące szacowania wartości nieruchomości, należy poznać przydatność metody porównawczej w ekonomii. Różnice w jej stosowaniu w poszczególnych dziedzinach ekonomii zaprezentowano w tabeli 2.

Tabela 2. Typologia dyscypliny naukowej „ekonomia”

\begin{tabular}{|l|l|l|}
\hline \multicolumn{1}{|c|}{ Metody i paradygmaty } & \multicolumn{1}{|c|}{ Nauki ścisłe (epistyme) } & \multicolumn{1}{c|}{ Nauki społeczne (doksa) } \\
\hline Metody ilościowe & Ekonomia (polityczna) & Finanse \\
\hline Metody jakościowe & Towaroznawstwo & Zarządzanie \\
\hline
\end{tabular}

Źródło: (Nauki ekonomiczne... 2015, s. 45).

Pomijając zagadnienie ekonomii jako źródła teorii wartości nieruchomości, wskazać należy, że dla teorii i praktyki szacowania wartości nieruchomości coraz większe znaczenie ma komparastyka finansów (Flejterski i Solarz 2015), o czym decydują silne związki rynków nieruchomości i finansowego ${ }^{4}$. $\mathrm{Z}$ nauki finansów przeniesiono do metodyki szacowania tylko narzędzia obliczeniowe, które dotyczą

\footnotetext{
${ }^{4}$ Pierwszy przykład dydaktyczny w publikacji monograficznej z obszaru finansów i inwestycji dotyczy analizy narzędziowej decyzji o zakupie spekulacyjnym nieruchomości (por. Kruschwitz 2007, s. 2).
} 
formuł metod dochodowych, ale istotniejsze znaczenie ma wykorzystywanie do porównawczego szacowania wartości nieruchomości typowych narzędzi ilościowych zapożyczonych od analityków działających na rynkach finansowych. Techniki, w tym AVM (Mooya 2016, s. 67 i nast.), zapożyczone z obszaru wycen niematerialnych i nietrwałych aktywów finansowych powiązanych bazowo z nieruchomościami (np. hipotek i instrumentów pochodnych tworzonych na ich postawie) przeniesiono do szacowania wartości nieruchomości, które funkcjonują na rynku o odmiennej charakterystyce. Wcześniej jednak sposób wykonywania porównań w szacowaniu wartości nieruchomości ukształtowano z wykorzystaniem utrwalonego dorobku towaroznawstwa. Wypracowane tam metody punktowe umożliwiają bowiem porównywanie cech obiektów z elastycznością ich ujmowania przez opisy, liczby, cechy ciągłe lub skokowe, analizy jedno- lub wielowymiarowe (Nauki ekonomiczne... 2015, s. 52). Zwrócić należy uwagę, że w każdym przypadku przeniesiono z ekonomii do szacowania wartości nieruchomości jedynie wybrane narzędzia lub ich części, które oryginalnie funkcjonują w innym otoczeniu metodologicznym. Przykładowo w finansach modele regresji wielorakiej czy wyceny opcji funkcjonują w otoczeniu teorii rynku efektywnego, która jest niejednoznaczna (Kruschwitz 2007, s. 246), a także odmienna od teorii wartości rynkowej. W przypadku towaroznawstwa wykorzystuje się metody badania i porównywania właściwości (wartości) użytkowych towarów, a techniki pozwalają na analizę i ocenę cechy użytkowych przy innych kryteriach konceptualizacji i operacjonalizacji badań. Z tego obszaru do metodyki szacowania przeniesiono zasadę ceteris paribus, ograniczając błędnie jej wykorzystanie do kontekstu narzędziowego z wyjaśnieniem jako ,pozostałe cechy równe” (Standardy zawodowe... 2002, Standard IX/III.7[*]/4). Zapomniano przy tym o kluczowym znaczeniu tego pojęcia „za ostatnich zgodnych warunków” (Schenk 2008, s. 24), co tworzy poprawne warunki do operacjonalizacji badań rynku nieruchomości, które mają prowadzić do odkrywania związków przyczyno-skutkowych. Bez wykonania tak rozumianej analizy dochodzi do sytuacji, w której znajomość rynku staje się tylko warunkiem stosowania metody (Standardy zawodowe... 2002, Standard IX/III.7[*]/1), a nie odrębnym i nadrzędnym elementem metodyki w modelu normatywnym. Aplikacja metody porównawczej z towaroznawstwa prowadzi wprost do przyjęcia narzędziowego modelu szacowania wartości nieruchomości, gdy nieruchomość podobna w MASR jest kształtowana przez techniczno-narzędziowe pojęcie próbki reprezentatywnej (Standardy zawodowe... 2002, Standard IX/III.7[*]/9) lub analiza rynku wykonywana jest tylko w celu ustalenia cech (atrybutów), a konceptualizacja wartości rynkowej ograniczona jest do najbardziej prawdopodobnej ceny (Hozer, Kokot i Kuźmiński 2002, s. 29 i 22).

Główny problem metodyczny, stanowiący ograniczenie stosowania narzędzi znanych i używanych w ekonomii, wynika z praktycznego wymiaru szacowania 
wartości nieruchomości, gdyż działalność ta prowadzi do przewidywania w czasie teraźniejszym pojedynczych zdarzeń gospodarczych (fenomenów), tj. wartości rynkowej konkretnej nieruchomości. Metodologia ekonomii dysponuje natomiast narzędziami, które służą do wyjaśniania szerszych zjawisk - klas faktów (Stachak 1997, s. 252). W tym ujęciu w szacowaniu jest miejsce na „sztukę wyceny”, która winna mieć charakter sformalizowany, a jego podstawą musi być profesjonalna interpretacja danych rynkowych, co odróżnia te czynności od nieformalnej wyceny opartej na wrażeniach czy intuicji (Betts i Ely 2008, s. 5). Takiej formalizacji nie można zastąpić tylko przez wykorzystanie rozbudowanego narzędzia pomiarowego, np. analizy regresji.

\section{Zasady porównywania w szacowaniu wartości nieruchomości w Polsce i USA}

W artykule porównywanie w szacowaniu wartości nieruchomości odnosi się do stosowania podejścia porównawczego ${ }^{5}$, które powinno być zobiektywizowane i ma prowadzić do określenia wartości rynkowej ${ }^{6}$. W każdej z trzech metod porównawczych obecne jest założenie, że „wartość ta odpowiada cenom, jakie uzyskano za nieruchomości podobne" (Ustawa z dnia 21 sierpnia 1997 r. ..., art. 153, ust. 1). Wskazuje to na metodyczne ujmowanie cen jako parametrów służących do pomiaru (określania) wartości, a nie cen jako badanych parametrów ekonomicznych, co ma miejsce w modelu pozytywnym wyceny. Konceptualizacja podejścia porównawczego wymaga przyjęcia dla wartości rynkowej modelu normatywnego. Cena nieruchomości podobnej wykorzystywana do porównań winna spełniać założenia, że analizowana transakcja miała być przeprowadzona w warunkach rynkowych, które nie zmieniły się istotnie od czasu jej zawarcia do daty wyceny. Wyznacza to kryteria poprawnej operacjonalizacji badań rynku pod kątem (warunków) czynników kształtujących konkurencję rynkową, gdyż zasada cetreris paribus oznacza przyjęcie do porównań transakcji spełniających warunek ostatnich zgodnych warunków funkcjonowania rynku. Z jednej strony regulacja wskazuje poprawnie na konieczność przestrzegania zasady status quo (Konowalczuk 2008, s. 70), z drugiej w praktyce powoduje wyłączenie z porównań cech

\footnotetext{
${ }^{5} \mathrm{~W}$ szerszym ujęciu w każdym podejściu korzysta się z zasady porównywania, a kluczowe znaczenie ma podobieństwo (Międzynarodowe standardy... 2005, s. 50).

${ }^{6}$ Pomimo regulacji prawnych, które wskazują na zastosowanie podejścia porównawczego i dochodowego do określania wartości rynkowej nieruchomości (por. Zarządzenie Ministra Gospodarki Przestrzennej i Budownictwa z dnia 1 marca 1995 r. ..., par. 5; Ustawa z dnia 21 sierpnia 1997 r. ..., art. 152, ust. 3), jest oczywiste, że można w ten sposób także oszacować inne rodzaje wartości (Rozporządzenie Rady Ministrów z dnia 21 września 2004 r...., par. 25 i 54).
} 
transakcji (warunków zawarcia), gdyż te mają być niewzruszone ${ }^{7}$. Wskazuje to na przyjęcie w podejściu porównawczym w Polsce wąskiego, typowo towaroznawczego, ujmowania cech nieruchomości, głównie jako ich właściwości prawnych i techniczno-użytkowych i pomijanie warunków zawarcia transakcji. Jest to podstawowa różnica praktyki krajowej w stosunku do teorii i praktyki wyceny prezentowanej w literaturze anglosaskiej (por. The Appraisal... 2013, s. 389; Betts i Ely 2008, s. 220). Krajowe rozwiązanie wspiera definicja prawna nieruchomości podobnej (Ustawa z dnia 21 sierpnia 1997 r. ..., art. 4, pkt 16), która nawiązuje do cech w ujęciu towaroznawczym. Regulacja ta dotyczy jedynie fazy pomiaru (stosowania metody wyceny). Powinna ją poprzedzić operacjonalizacja, która ma umożliwić wykonanie poprawnej analizy rynku. W tym zakresie brak ograniczeń prawnych do badania związków o charakterze przyczynowo-skutkowym. Przy przestrzeganiu zasady status quo nieruchomości podobne powinny mieć zbliżone ceny transakcyjne, a ich wybór dokonywany jest z perspektywy działania ludzi przy założeniu, że racjonalny nabywca nie zapłaci za pożądaną nieruchomość więcej, niż wynosi cena na tym rynku, w tym samym czasie za nieruchomość o podobnych cechach. Mamy więc do czynienia z oparciem wyceny na zrealizowanym (efektywnym) popycie (Kucharska-Stasiak 2016, s. 199). Przy zachowaniu rynkowych warunków zawierania transakcji ceny rynkowe nieruchomości podobnych prezentują ich wartości rynkowe, a do porównań w modelu normatywnym faktycznie wykorzystuje się wartości rynkowe nieruchomości podobnych (Sayce i in. 2006, s. 10-12). Różnice stosowania podejścia porównawczego w Polsce i USA prezentuje tabela 3. Wyodrębniono dwa obszary korekt stosowanych w USA, które dotyczą cech transakcji i cech nieruchomości. W ostatniej kolumnie oceniono możliwości stosowania tego rodzaju korekt dla MASR w Polsce.

Tylko pozornie można by uznać, że główne różnice wynikają z pomijania w porównaniach w Polsce cech transakcji i ograniczenia się do korekt cech nieruchomości. W Polsce $\mathrm{w}$ ramach podejścia porównawczego przeprowadza się jedynie czynność sprowadzenia wartości nieruchomości podobnych do poziomu cen bieżących przez tzw. trend „uwzględnienie upływu czasu” (Ustawa z dnia 21 sierpnia 1997 r. ..., art. 153, ust. 1). Na przeszkodzie korygowania cech transakcji stoją regulacje prawne z kluczową definicją nieruchomości podobnej (Ustawa z dnia 21 sierpnia 1997 r. ..., art. 4, pkt 16). Oprócz różnic dotyczących braku porównań cech transakcji występują również różnice w zakresie porównywania w Polsce i USA cech nieruchomości. Wynika to z różnych perspektyw operacjonalizacji procesu wyceny w zakresie analizy rynku. Poszukiwanie cech rynkowych do porównań jest w USA poprzedzone nadrzędną konceptualizacją

7 Zachowane mają być rygorystycznie sformułowane warunki rynkowe, np. wyłączające jako źródła informacji także transakcje z odroczonymi terminami płatności czy wydania nieruchomości (Rozporządzenie Rady Ministrów z dnia 21 września 2004 r...., par. 5, pkt 3). 


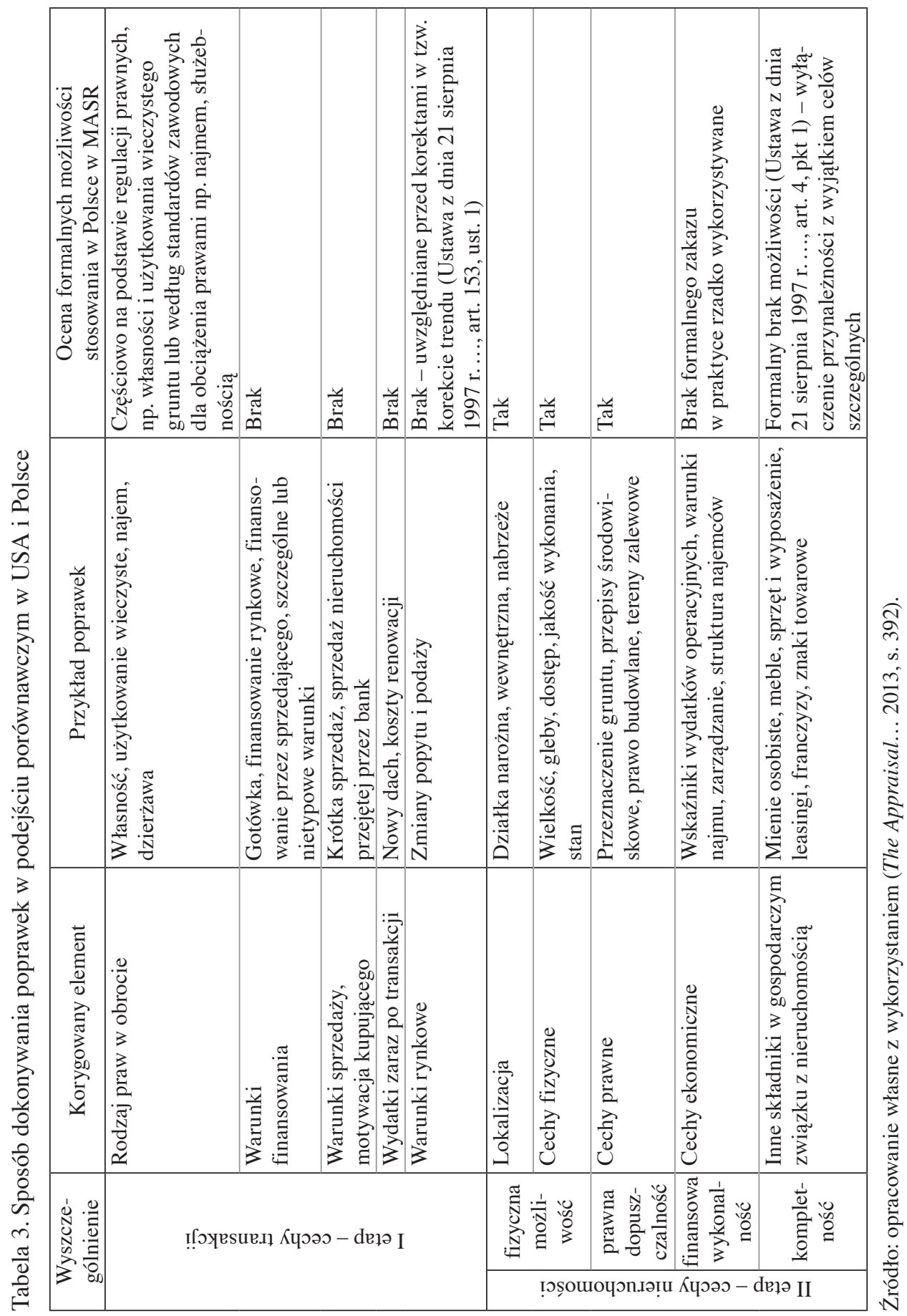


dotyczącą definiowania i interpretacji wartości rynkowej według analizy optymalnego sposobu użytkowania i jej podporządkowane (highets and best use - HBU). Służy to wyznaczeniu kryteriów operacjonalizacji analizy rynku i pozwala na pogrupowanie cech według właściwości: fizycznych, prawnych i ekonomicznych ${ }^{8}$, które wyznaczane są z perspektywy uczestników rynku (działania ludzi). Cechy nieruchomości rozumiane są w kontekście spełniania warunku dobrej porównywalnej sprzedaży, która ma stanowić alternatywę dla nabywcy (The Appraisal... 2013, s. 121). Perspektywa hipotetycznego nabywcy wymaga włączenia do porównań cech transakcji (transactional adjustments), które są korygowane. Zmienia to perspektywę podobieństwa z ujęcia towaroznawczego i narzędziowego na rynkową, determinowaną oczekiwaniami nabywców, którzy wybierają zgodnie z założeniem obojętnej alternatywy inwestycyjnej. Wspiera to operacjonalizacja badań rynku według zasady dla ostatnich zgodnych warunków, w praktyce odzwierciedlają to zasady wyceny: popytu i podaży, konkurencji oraz substytucji (Konowalczuk 2008, s. 37). Weryfikacja cech transakcji umożliwia uzyskanie informacji o motywacjach kupującego i sprzedającego, które nie dotyczą cech towaroznawczych nieruchomości, ale ujmują problem zgodnie z zasadą antycypacji i zmiany (Rattermann 2011, s. 2005). Analiza danych dotyczy: rodzaju sprzedanych praw do nieruchomości, warunków finansowania, motywacji kupujących i sprzedających, wydatków dokonanych zaraz po zakupie i ich dat oraz - oprócz typowych cech (lokalizacji, stanu technicznego, funkcjonalności) - także aspektów ekonomicznych, sposobu użytkowania i elementów niematerialnych (Mills 2016, s. 224 i nast.). W przeciwieństwie do metod ilościowych, w których korzysta się najczęściej z całości dostępnych danych, w przypadku metod porównawczych w USA za bardzo ważne uznaje się dobór i uzgadnianie zbiorów danych porównawczych, a kryteria wyboru dotyczą oceny podobieństwa - według koncepcji HBU jako rozsądnej alternatywy dla przedmiotowej nieruchomości. Metody statystyczne mogą być natomiast stosowane do obliczania poprawek do cen transakcyjnych nieruchomości podobnych. Stosując analizę statystyczną, rzeczoznawca musi uważać, by nie doprowadzić do sytuacji, w której wynik jest matematycznie precyzyjny, ale pozbawiony sensu lub niewłaściwy dla danej wyceny. Podobnie jak w przypadku innych sposobów ustalania poprawek analiza statystyczna musi odzwierciedlać procesy myślowe i wnioskowanie uczestników rynku, aby służyć jako użyteczne i przekonujące narzędzie analizy i wyceny (The Appraisal... 2013, s. 400). Konceptualizacja procesu wyceny wymaga uznania nieefektywności jako immanentnej cechy rynku nieruchomości oraz przyjęcia, że trudności w wyrażaniu korekt (poprawek) z matematyczną precyzją są obiektywnie uzasadnione (The Appraisal... 2013, s. 403).

\footnotetext{
${ }^{8}$ Dla uproszczenia rozważań pominięto czwarty element HBU dotyczący maksymalnej produktywności.
} 


\section{Zakończenie i wnioski}

Warunki korzystania z MASR w Polsce zostały ukształtowane przez regulacje prawne, na niskim poziomie instrukcji i przepisów wykonawczych, bez uwzględnienia wymaganego uporządkowania w ramach teorii wyceny, a także przy braku refleksji na temat stosowania metod porównawczych w metodologii ekonomii. MASR charakteryzuje w stosunku do klasycznych porównań autonomiczność w zakresie narzędzi. Różni się ona także w zakresie metodycznym od porównywania w ekonomii, gdyż inna jest teoria, sposób stosowania i cel. Ocena różnic pomiędzy porównaniami ilościowymi i jakościowymi w szacowaniu wartości nieruchomości wymaga wcześniejszego uporządkowania metodycznego, a nie tylko oceny narzędziowej (metody). Można do tego wykorzystać kryteria stosowane w przypadku metody porównawczej w ekonomii, co zaprezentowano w tabeli 4.

Tabela 4. Uporządkowanie metodyczne ilościowych i jakościowych metod w szacowaniu wartości nieruchomości na podstawie kryteriów stosowanych w metodzie porównawczej w ekonomii

\begin{tabular}{|l|l|l|}
\hline \multicolumn{1}{|c|}{$\begin{array}{c}\text { Aspekt } \\
\text { metodyczny }\end{array}$} & \multicolumn{1}{|c|}{ Metody ilościowe } & \multicolumn{1}{c|}{ Metody jakościowe } \\
\hline Obiekt porównań & Nieruchomość (własność rzeczy) & Transakcja dotycząca nieruchomości \\
\hline $\begin{array}{l}\text { Właściwości } \\
\text { obiektu }\end{array}$ & $\begin{array}{l}\text { Towaroznawczo ujęte cechy prawne, } \\
\text { fizyczne i częśc ekonomicznych }\end{array}$ & $\begin{array}{l}\text { Tylko cechy rynkowe, kompleksowo } \\
\text { ujęte i wywiedzione wcześniej } \\
\text { z rynku na podstawie analizy HBU } \\
\text { oraz warunki zawierania transakcji }\end{array}$ \\
\hline Przykład metody & Regresja wieloraka & Porównywanie parami \\
\hline Zasada porównań & Korelacja i prawdopodobieństwo & Związki przyczynowo-skutkowe \\
\hline Cel & Analiza rynku lub określenie wartości & Określenie wartości \\
\hline Wynik & Wartość rynkowa & - \\
\hline
\end{tabular}

Źródło: opracowanie własne.

Metody ilościowe różnią się od klasycznych metod jakościowych (np. porównywania parami): ujęciem obiektu porównań, zakresem opisu właściwości nieruchomości i stosowaną zasadą porównań, co powoduje brak uzasadnienia dla zaliczania MASR do klasycznego podejścia porównawczego. W tym kontekście ocenić należy, że MASR najczęściej nie pozwala na przeprowadzenie porównań, które odzwierciedlałyby zachowania dość wąskich grup uczestników rynku konkurujących o nieruchomości podobne z popytowego punktu widzenia. Ponadto metody ilościowe mają szersze zastosowanie i stanowią ważną metodę analizy rynku. Uzasadnieniem dla stosowania podejścia porównawczego jest przede wszystkim 
naśladowanie oraz przeprowadzenie obiektywizującej oceny zachowania uczestników rynku, głównie kupujących, w kontekście nadrzędnej koncepcji wartości rynkowej i przy operacjonalizacji uwzględniającej stan konkurencji na właściwym rynku. Tak rozumiane podejście porównawcze zachowuje wymaganą metodyczną kompleksowość i zasadę symetrii pomiędzy celem i okolicznościami szacowania a stosowanym narzędziem (metodą). MASR nie spełnia tych warunków i nie może być zaliczona do podejścia porównawczego.

W metodologii nauk ekonomicznych wskazuje się na większą skuteczność badań ilościowych przy dużej liczebności badanych populacji, ale nie dotyczy to badań złożonych problemów, w których preferuje się badania jakościowe (Nauki ekonomiczne... 2015, s. 46). Wyznacza to dwa niezbędne i współzależne kryteria oceny przydatności MASR w szacowaniu wartości nieruchomości. Błędem metodycznym byłoby bowiem przyjęcie tylko kryterium ilościowego, co stanowiło zasadniczą (lub raczej nawet jedyną) przesłankę dla administracji przy dopuszczeniu MASR jako uniwersalnej metody szacowania wartości nieruchomości (Tymczasowe zasady... 1994, s. 36). Problem dotyczy relacji pomiędzy ,jak?” (how?) i „dlaczego?” (why?). Rzeczywiście większa liczba danych nie poprawia jakości wnioskowania przy złożonej rzeczywistości nawet w ekonomii, gdzie metody ilościowe zostały zasadniczo przewidziane do badania klas zjawisk. Analogicznie będzie w szacowaniu wartości nieruchomości, gdzie dodatkowo konieczne jest badanie związków o charakterze przyczynowo-skutkowym w kontekście pojedynczych zdarzeń. Żadna rozbudowana formuła matematyczna nie zastąpi bowiem w warunkach złożoności badanej rzeczywistości, gdyż „wiedza, jak liczyć, nie może wiele pomóc, kiedy nie wie się, co liczyć" (Whyte 2015, s. 41).

W Polsce właściwe byłoby wyłączenie MASR z podejścia porównawczego i rekomendowanie stosowania do szacowania w procesach masowej wyceny, np.: aktualizacji opłat rocznych za użytkowanie wieczyste, wyceny odszkodowań dla obiektów liniowych i obszarów ograniczonego użytkowania, oceny skutków finansowych zmian planów miejscowych oraz dla celów zarządzaniem ryzkiem banków przy finansowaniu rynku nieruchomości z wykorzystaniem hipoteki. Takie postulaty formułowano już na początku lat 90. XX w. (Hopfer i in. 1994, s. 113).

\section{Literatura}

Adamczewski Z. (2006), Elementy modelowania matematycznego w wycenie nieruchomości. Podejście porównawcze, Oficyna Wydawnicza Politechniki Warszawskiej, Warszawa.

The Appraisal of Real Estate 14th Edition (2013), Appraisal Institute, Chicago.

Ayau M.F. (2010), Paradoks wymiany, Fijorr Publishing, Warszawa. 
Babbie E. (2005), Badania społeczne w praktyce, Wydawnictwo Naukowe PWN, Warszawa.

Barańska A (2007), Dwuetapowy model wyceny nieruchomości, „Studia i Materiały Towarzystwa Naukowego Nieruchomości”, nr 3-4, Rynek nieruchomości - analizy, modelowanie, inwestowanie.

Betts R.M., Ely S.J. (2008), Basic Real Estate Appraisal: Principles and Procedures, 7th ed., Thomson South-Western, Mason.

Canonne J., Macdonald R. (2003), Valuation without Value Theory: A North American “Appraisal”, ,Journal of Real Estate Practice and Education”, vol. 6, nr 1.

Czaja J. (2004), Merytoryczna analiza procedur szacowania rynkowej wartości nieruchomości w podejściu porównawczym, ,Studia i Materiały Towarzystwa Naukowego Nieruchomości", nr 1.

Dell G. (2004), AVMs: The Myth and the Reality; The Problem and the Solution, „Valuation Insights and Perspectives", vol. 9(3).

Dell G. (2013), Common Statistical Errors and Mistakes: Valuation and Reliability, „The Appraisal Journal”, Fall.

Dydenko J., Telega T. (2016), Wycena nieruchomości. Komentarz do ustawy o gospodarce nieruchomościami oraz Rozporządzenia Rady Ministrów w sprawie wyceny nieruchomości i sporzadnia operatu szacunkowego, Wolters Kluwer, Warszawa.

Europejskie standardy wyceny 2000 (wydanie polskie) (2001), PFSRM, Warszawa.

Flejterski S., Solarz J.K (2015), Komparastyka finansów, Wydawnictwo C.H. Beck, Warszawa.

Foryś I. (2012), Zakres analizy rynku a cel i przedmiot szacowania - teoria i praktyka, „Rzeczoznawca Majątkowy”, nr 2(74).

Foryś I. (2014), Wykorzystanie analizy dyskryminacyjnej do typowania rynków podobnych w procesie wyceny nieruchomości niemieszkalnych, „Prace Naukowe Uniwersytetu Ekonomicznego we Wrocławiu", nr 328, Taksonomia 23. Klasyfikacja i analiza danych - teoria i zastosowania.

Foryś I. (2017), Ocena podobieństwa wielowymiarowych obiektów w wycenie nieruchomości zabudowanych domami jednorodzinnymi, „Prace Naukowe Uniwersytetu Ekonomicznego we Wrocławiu”, nr 469, Taksonomia 29. Klasyfikacja i analiza danych - teoria i zastosowania.

Foryś I., Batóg B. (2011), Modele logitowe $w$ analizie transakcji na warszawskim rynku mieszkaniowym, „Studia i Materiały Towarzystwa Naukowego Nieruchomości”, vol. 19 , t. 3.

Foryś I., Gaca R. (2016a), Modelowanie zmiennych jakościowych w procesie wyceny nieruchomości z wykorzystaniem skali semantycznej Osgooda na przykładzie wybranego segmentu rynku mieszkaniowego (w:) Nieruchomość w przestrzeni 2, red. M. Trojanek, Uniwersytet Ekonomiczny w Poznaniu, Poznań.

Foryś I., Gaca R. (2016b), Teoretyczne i praktyczne aspekty opisu cech jakościowych nieruchomości $w$ modelach regresji wielorakiej wyceny wartości mieszkan, „Zeszyty Naukowe Uniwersytetu Ekonomicznego w Krakowie” nr 9(957), https://doi. org/10.15678/ZNUEK.2016.0957.0906.

Hopfer A., Jedrzejewski H., Źróbek R., Źróbek S. (1994), Wycena nieruchomości i przedsiębiorstw, t. 1, Twigger, Warszawa.

Hozer J. (2001), Regresja wieloraka a wycena nieruchomości, „Rzeczoznawca Majątkowy", nr 2. 
Hozer J., Kokot S., Kuźmiński W. (2002), Metody analizy statystycznej rynku w wycenie nieruchomości, Wydawnictwo PFSRM, Warszawa.

Kane M.S., Linne M.R., Johnson J.A. (2004), Practical Applications in Appraisal Valuation Modeling: Statistical Methods for Real Estate Practitioners, Appraisal Institute, Chicago.

Kokot S. (2011), Metoda analizy statystycznej rynku w teorii i praktyce wyceny nieruchomości. Wstęp do dyskusji nad przyszła norma zawodowa, ,Przegląd Geodezyjny”, t. 83, nr 3 .

Konowalczuk J. (2008), Wycena nieruchomości przedsiębiorstw, Wydawnictwo C.H. Beck, Warszawa.

Konowalczuk J. (2017). The Problem of Reflecting the Market in the Legal Principles of Real Estate Valuation in Poland. How to Eliminate the "Legal Footprint”?, „Real Estate Management and Valuation", vol. 25, nr 2, https://doi.org/10.1515/remav-2017-0012.

Kosmulska S. (2016), Warsztat rzeczoznawcy majątkowego - metody wyceny, http://pirm. $\mathrm{pl} /$ wypowiedzi-ekspertow-pirm/135-warsztat-rzeczoznawcy-majtkowego-metody-wyceny.html (data dostępu: 12.07.2017).

Kruschwitz L. (2007), Finansowanie i inwestycje, CeDeWu, Warszawa.

Kucharska-Stasiak E. (2016), Ekonomiczny wymiar nieruchomości, Wydawnictwo Naukowe PWN, Warszawa.

Małecki Z. (2016), Rzeczoznawca majątkowy. Wybrane uwarunkowania określania wartości nieruchomości, PFSRM, Warszawa.

Międzynarodowe standardy wyceny 2005 (2005), PFSRM, Warszawa.

Międzynarodowe standardy wyceny 2007 (2009), PFSRM, Warszawa.

Mills M.C. (2016), Residential Elements of Comparison - Transactional Adjustments, „The Appraisal Journal”, Fall.

Mooya M.M. (2016), Real Estate Valuation Theory. A Critical Appraisal, Springer-Verlag, Berlin-Heidelberg.

Nauki ekonomiczne. Stylizowane fakty a wyzwania współczesności (2015) red. B. Fiedor, PTE, Warszawa.

Pasymowski E. (2006), Econometric Solutions for Real Estate Valuation Automated Valuation Models - Friend or Foe?, Proceedings of the 23rd Pan Pacific Congress of Real Estate Appraisers, Valuers and Counselors, San Francisco, September.

Rattermann R.M. (2011), Could Sherlock Holmes Find Clues to Market Value in This Market?, „The Appraisal Journal”, Summer.

Robinson S.I., Sanderford A.R. (2016), The Effects of Conditions and Context on Office Building Sales, 2002-2011, ,The Appraisal Journal”, vol. 84, nr 4.

Rozporządzenie Rady Ministrów z dnia 7 lipca 1998 r. w sprawie szczegółowych zasad wyceny nieruchomości oraz zasad i trybu sporządzania operatu szacunkowego, Dz.U. nr 98, poz. 612.

Rozporządzenie Rady Ministrów z dnia 27 listopada 2002 r. w sprawie szczegółowych zasad wyceny nieruchomości oraz zasad i trybu sporządzania operatu szacunkowego, Dz.U. nr 230, poz. 1924.

Rozporządzenie Rady Ministrów z dnia 21 września 2004 r. w sprawie wyceny nieruchomości i sporządzania operatu szacunkowego, Dz.U. nr 207, poz. 2109 z późn. zm.

Rozporządzenie Rady Ministrów z dnia 29 czerwca 2005 r. w sprawie powszechnej taksacji nieruchomości, Dz.U. nr 131, poz. 1092.

Sawiłow E. (2010), Problematyka określania wartości nieruchomości metodą analizy statystycznej rynku, ,Studia i Materiały Towarzystwa Naukowego Nieruchomości”, nr 1. 
Sayce S. i in. (2006), Property Appraisal: From Value to Worth, Blackwell Publishing, Oxford.

Schenk J. (2008), Analiza przyczynowa w systemach rekursywnych: podejścia i podstawowe metody, Wydawnictwo Wyższej Szkoły Informatyki i Zarządzania, Rzeszów.

Stachak S. (1997), Wstęp do metodologii nauk ekonomicznych, Książka i Wiedza, Warszawa.

Standardy zawodowe rzeczoznawców majątkowych (2002), PFSRM, Warszawa.

Trimble M.C. (2014), Comments on "Common Statistical Errors and Mistakes: Valuation and Reliability”. Letters to the Editor, „The Appraisal Journal”, vol. 89(2), Spring.

Tymczasowe zasady wyceny nieruchomości (1994), Ministerstwo Gospodarki Przestrzennej i Budownictwa, Warszawa, wrzesień.

Ustawa z dnia 21 sierpnia 1997 r. o gospodarce nieruchomościami, Dz.U. nr 115, poz. 741 ze zm. do sierpnia $2017 \mathrm{r}$.

Whyte J. (2015), Oszuści czy ignoranci. O nadużywaniu nauki do celów politycznych, Fijorr Publishing, Warszawa.

Wolverton M.L. (2014), Comments on "Common Statistical Errors and Mistakes: Valuation and Reliability”. Letters to the Editor, „The Appraisal Journal”, Spring.

Wyrok SA w Poznaniu z dnia 14 kwietnia 2016 r., I ACa 1276/15.

Wyrok SO w Gliwicach z dnia 2 grudnia 2014 r., XVI C 824/14.

Wyrok SO w Łodzi z dnia 4 maja 2016 r. (a), II C 666/14.

Wyrok SO w Łodzi z dnia 4 maja 2016 r., II C 666/14.

Wyrok SO w Poznaniu z dnia 21 kwietnia 2016 r., XII C 1183/14.

Wyrok SO w Warszawie z dnia 22 lutego 2016 r., XVI GC 618/14.

Wyrok SO w Warszawie z dnia 24 maja 2016 r., IV C 891/15.

Wyrok WSA w Gliwicach z dnia 25 września 2013 r., II SA/Gl 1480/12.

Wyrok WSA w Gliwicach z dnia 20 marca 2015 r., II SA/Gl 1343/14.

Wyrok WSA w Warszawie z dnia 25 marca 2004 r., I SA 1607/02.

Wyrok WSA we Wrocławiu z dnia 19 marca 2004 r., II SA/Wr 643/01.

Zarządzenie Ministra Gospodarki Przestrzennej i Budownictwa z dnia 1 marca 1995 r. w sprawie szczegółowych zasad ustalania wartości nieruchomości, M.P. nr 13, poz. 163 .

Zbyrowski R. (2010), Szacowanie wartości nieruchomości na podstawie modeli ekonometrycznych, „Equilibrium”, nr 1(4).

\section{Comparison in Statistical Market Analysis Method Used for Real Estate Valuation in Poland}

(Abstract)

In Poland, the statistical market analysis method (SMAM) is a comparative approach. This classification differs from the real estate valuation theory and practice employed in mor developed markets, e.g. in the US. This real estate valuation method does not involve making comparisons that would reflect the behaviour of market participants. The aim of this article is to evaluate SMAM in connection with the comparative method applied in economics and in relation to real estate valuation theory and practice, taking into account current judicial rulings, and to present an outline of the development of this method in Poland. The article is based on studies of domestic and foreign literature, 
a comparative study of Polish and American methodology, and a critical analysis of judicial rulings. The author proposes that SMAM be excluded from the comparative approach, which is designed to determine the market value of individual properties and be used instead to valuate real estate for tax purposes.

Keywords: real estate valuation methodology, statistical market analysis, comparison in economics and real estate valuation, mass valuation, valuation for tax purpose. 